\title{
THE INFLUENCE OF MARKETING MIX ON DECISIONS TO BE A ISLAMIC BANKING CUSTOMER IN CIANJUR REGENCY
}

\author{
Uus Ahmad Husaeni
}

Fakultas Ekonomi dan Bisnis Islam Universitas Suryakancana

Email: uusahmadhusaeni@unsur.co.id

\section{Abstract}

The people's decision to choose Islamic banking in Cianjur regency is very low. Currently, Islamic banking customers in Cianjur regency are only about $5-8 \%$ of the total population of 2,335 million people. In fact, $98 \%$ of the population in Cianjur regency is Muslim, and this city is also known as "santri city". Therefore, it is necessary to test whether the marketing mix that includes product, price, place, and promotion can affect the decision to become a customer of Islamic banking. This study aims to examine the effect of product, price, place, and promotion on the decision to become a customer of Islamic banking. Analysis tool used in this research is multiple linear regression analysis. The result of the research, simultaneously shows that product, price, place, and promotion have 
significant effect to the decision to become Islamic banking customer, while the rest is explained by other factors not included in this research.

Keywords: Marketing Mix; Customer; Multiple Linear Regression and Islamic Banking.

\section{Abstrak}

Keputusan masyarakat untuk memilih perbankan syariah di Kabupaten Cianjur sangat rendah. Saat ini, nasabah perbankan syariah di Kabupaten Cianjur hanya sekitar 5-8 \% dari total penduduk yang berjumlah 2.335 juta jiwa. Padahal, $98 \%$ penduduk di Kabupaten Cianjur beragama Islam yang juga dikenal sebagai kota santri. Oleh karena itu, perlu dilakukan pengujian apakah marketing mix yang meliputi produk, harga, tempat, dan promosi mampu mempengaruhi keputusan menjadi nasabah perbankan syariah. Penelitian ini bertujuan untuk menguji pengaruh produk, harga, tempat, dan promosi terhadap keputusan menjadi nasabah perbankan syariah. Alat analisis yang digunakan dalam penelitian ini adalah analisis regresi linear berganda. Hasil penelitian, secara simultan menunjukkan bahwa produk, harga, tempat, dan promosi berpengaruh signifikan terhadap keputusan menjadi nasabah perbankan syariah, sedangkan sisanya dijelaskan oleh faktor lain yang tidak diikutsertakan dalam penelitian ini.

Kata Kunci: Marketing Mix; Nasabah; Regresi Linear Berganda dan Perbankan Syariah. 


\section{INTRODUCTION}

The competition in the field of banking industry in Indonesia today becomes increasingly tight. Where the development of the number of private banks and sharia banks continues to increase rapidly. Because of such competition, it means there have been changes in the marketing strategy in order to optimize banking services (Erol, 1990: 25-35). The growing prospect of the banking industry demands that banking institutions must have the right strategy to market their products and services. One the form of marketing strategy that is suitable to be implemented is the marketing mix.

According to Kotler and Armstrong (2014), marketing mix is a specific blend of advertising, sales promotion, public relations, personal sales, and direct marketing tools that companies use to communicate persuasively about customer value and build customer relationships. Meanwhile, according to Peter and Olson (2013: 187-188), marketing mix is all the elements that form all the elements of marketing components such as employee ability, price, distribution, advertising, product, place, process, and physical evidence as part of the company's marketing mix . Some experts say the same about the main $4 \mathrm{P}$ in marketing mix as proposed by Fandi Tjiptono (2011), 4P means product (product), price (place) and place (promotion) ). In its development, the development of service marketing mix becomes more widespread. According to Yazid (2005: 18), there is an addition of existing $4 \mathrm{P}$ to $7 \mathrm{P}$ with the addition of people, physical evidence (physical environment in which services are provided), and process. In line with Yazid, Valarie A. Zeithaml and Mary Jo. Bitner (2011: 26) argues that people, physical evidence, and process are also a marketing mix dimension.

It is expected that by applying the right promotional strategy can directly reach the desired target market, as well as to create a good image for the company. The diversity of products and services offered by banking institutions not only provides a wider opportunity for consumers to choose a banking institution that suits their needs, but also raises doubts as there are too many options offered by these banking institutions. On the other hand, consumers' enthusiasm to seek information from various sources before deciding to become a customer in a bank are some things that 
bank companies must consider (Murti Sumarni, 2002: 64). Therefore, financial institutions need to monitor the consumer behavior in making decisions and considerations if they will save their money in the bank.

Companies or banking institutions that will appear to winthecustomersarecompanis or banking institutions that truly understand the needs, demands and desires of consumers or customers. Companies must understand exactly who the target market is as well as how consumer behavior towards products and services offered. Marketing mix provides an enormous opportunity to the interests of companies and their customers. Companies should also give their time to learn the behavior of consumers.

The people's decision to choose sharia banking in Cianjur regency is very low. Currently, Islamic banking customers in Cianjur regency are only about $5-8 \%$ of the total population of 2,335 million people. While banking users reached 42.37 percent of the total population in Cianjur regency. In fact, $98 \%$ of the population in Cianjur regency are Muslims, this city is also known as santri city (Uus Ahmad Husaeni, 2017: 1117-1121). It supposed that the people's decision to choose Islamic banks in Cianjur regency would be high because of the factor of religiosity motivation. This is a big question for the researcher, what factors are the most dominant in increasing the number of customers of sharia banking in Cianjur regency. Therefore, the researcher tries to discuss this issue in the form of a research entitled "The influence of Marketing Mix (Product, Price, Place and Promotion) on the decision to be a sharia banking customer in cianjur district". This research, will examine the factors that influence the people's decision to become syariah banking customers by using marketing mix approach consisting of product, price, place and promotion as independent variable.

\section{METHOD}

This research used purposive sampling method in questionnaire which is a method of distributing questionnaires compiled from the indicator of dependent variable and independent variable to the respondent, meet and interact directly with the respondent who has permanent job. Then the questionnaire, distributed to 100 respondents who have criteria of having a permanent 
job in Cianjur regency.

According to Sugiono

(2007: 67), validity is an instrument related to the ability of the instrument to measure or reveal the characteristics of the variables intended to be measured. Meanwhile, according to Suharsimi Arikunto (2003: 88), validity is a condition that describes the level of relevant instruments' ability to measure what will be measured. According Singgih Santoso (2012:56-57), reliability is an index that shows the extent to which a measuring instrument can be trusted or reliable. When a measurement instrument is used twice to measure the same conditions and the measured results are relatively consistent, then the measurement instrument is considered reliable. Meanwhile, according to Anton Nugroho John (2011: 28), reliability shows the extent to which the measurement instrument's results can be trusted. The measurement results should be reliable in terms of having a consistency and stability level. A variable can be reliably labeled when it exceeds 0.6 of Cronbach's Alpha.

To achieve the objectives of this research, first classic assumption test is done to ascertain whether multiple linear regression model used does not have problem of normality, multicolonierity, heteroscedasticity and autocorrelation (Uus Ahmad Husaeni, 2017: 49-62). The objective is to provide assurance that the regression equation obtained has precision in estimation, unbiased and consistent with the use of SPSS 22.

The significance test of the independent variable $\left(X_{1}\right)$ on the dependent variable (Y) either simultaneously or partially on hypothesis $1\left(\mathrm{H}_{1}\right)$ to hypothesis $4\left(\mathrm{H}_{4}\right)$ is done by F-test (F-test) and t-test (T-test) at the 5\% level ( $\alpha=0.05)$ (Elis Ratna Wulan, 2015: 27-37).

To test how big the influence of dependent variable that is marketing mix (product, price, place, and promotion) to decision on becoming sharia banking customer, hence used multiple linear regression analysis with model as follows:

$$
\begin{aligned}
& Y=a+b_{1} X_{1}+b_{2} X_{2}+b_{3} X_{3}+ \\
& b_{4} X_{4}+e \\
& \text { Information: }
\end{aligned}
$$

$\mathrm{Y}=$ Decision to become a customer of Islamic banking $X_{1}=$ Product

$X_{2}=$ Price

$\mathrm{X}_{3}^{2}=$ Place

$X_{4}^{3}=$ Promotion

The magnitude of the constants is reflected in "a" and the magnitude of the regression coefficients of each 
independent variable is shown by $b^{1}, b^{2}, b^{3}$, and $b^{4}$ (Dadang Husen Sobana, 2016: 78-87).

\section{RESULTS \\ DISCUSSION Results}

Validity and reliability tests were conducted to find out how many valid and reliable questions by conducting a survey of 100 respondents. The results of the calculation of validity and reliability are

as follows:

Based on Table 1, it is known that all items present in each variable are valid as AND positive $(+)$ and the value is greater than 0.1966 ( $\mathrm{r}$ table) with $\mathrm{df}=\mathrm{n}-2$ or $\mathrm{df}=98$. Cronbach Alpha value of each variable Greater than 0.6 , which ranges from $0.870-0.875$, so both variables are declared trusted or reliable.

Based on F-test, the effect of the simultaneously four independent variables

\section{Table 1}

Test of Product Validity and Reliability, Price, Place, and Promotion on the Decision on Becoming a Customer of Sharia Banking

\begin{tabular}{|c|c|c|c|}
\hline Variable & Item & Correlated Items & Cronbach's Alpha \\
\hline \multirow{3}{*}{ Product } & P1 & 0.447 & \multirow{3}{*}{0.872} \\
\hline & P2 & 0.229 & \\
\hline & P3 & 0.605 & \\
\hline \multirow{3}{*}{ Price } & PC1 & 0.303 & \multirow{3}{*}{0.874} \\
\hline & PC2 & 0.552 & \\
\hline & PC3 & 0.673 & \\
\hline \multirow{3}{*}{ Place } & PL1 & 0.623 & \multirow[b]{3}{*}{0.870} \\
\hline & PL2 & 0.573 & \\
\hline & PL3 & 0.561 & \\
\hline \multirow{5}{*}{ Promotion } & PM1 & 0.443 & \multirow{5}{*}{0.875} \\
\hline & PM2 & 0.552 & \\
\hline & PM3 & 0.669 & \\
\hline & PM4 & 0.415 & \\
\hline & PM5 & 0.246 & \\
\hline \multirow{4}{*}{$\begin{array}{l}\text { Pecision on } \\
\text { becoming a } \\
\text { costumer }\end{array}$} & D1 & 0.443 & \multirow{4}{*}{0.873} \\
\hline & D2 & 0.552 & \\
\hline & D3 & 0.669 & \\
\hline & D4 & 0.392 & \\
\hline
\end{tabular}


of product, price, place, and (34.052)> F-table (2.47), the promotion on the dependent regressionmodel can be used to variable of decision to become predict the dependent variable the customer of sharia banking of decision to be a customer or

Table 2

ANOVA $^{a}$

\begin{tabular}{|cc|c|c|c|c|c|}
\hline \multicolumn{1}{|c|}{ Model } & $\begin{array}{c}\text { Sum of } \\
\text { Squares }\end{array}$ & Df & $\begin{array}{c}\text { Mean } \\
\text { Square }\end{array}$ & F & Sig. \\
\hline \multirow{2}{*}{1} & Regression & 276.604 & 4 & 69.151 & 249.731 & $.000^{\mathrm{b}}$ \\
& Residual & 26.306 & 95 & .277 & & \\
& Total & 302.910 & 99 & & & \\
\hline
\end{tabular}

a. Dependent Variable: Decision_Become_Costumer

b. Predictors: (Constant), Promotion_X4, Product_X1, Place_X3, Place_X2

as follows:

simultaneously independent Based on the F-Test, the result variable of product, price, is that the F-count value is place and promotion affect the

Table 3

T-test results

Coefficients $^{\mathrm{a}}$

\begin{tabular}{|c|c|c|c|c|c|}
\hline \multirow{2}{*}{$\begin{array}{c}\text { Model } \\
\text { B }\end{array}$} & \multicolumn{2}{|c|}{$\begin{array}{l}\text { Unstandardized } \\
\text { Coefficients }\end{array}$} & $\begin{array}{c}\text { Standardized } \\
\text { Coefficients }\end{array}$ & \multirow[t]{2}{*}{$\mathrm{T}$} & \multirow[t]{2}{*}{ Sig. } \\
\hline & $\begin{array}{l}\text { Std. } \\
\text { Error }\end{array}$ & Beta & & & \\
\hline (Constant) & -.228 & .508 & & -.450 & .654 \\
\hline Product_X $X_{1}$ & .071 & .060 & .055 & 1.178 & .242 \\
\hline Price_X $X_{2}$ & .252 & .076 & .205 & 3.321 & .001 \\
\hline Place_X $X_{3}$ & . 162 & .057 & 149 & 2.857 & .005 \\
\hline $\begin{array}{l}\text { Promo- } \\
\text { tion_X }\end{array}$ & .521 & .044 & .628 & 11.732 & .000 \\
\hline
\end{tabular}

249,731 with the significance dependent variable. level of 0.000 . Since the Based on the results of T-test significance level is less than above then the regression 0.05, and the F-count value equation is: 


$$
\begin{gathered}
Y=-0.228+0.071 X_{1}+ \\
0.252 X_{2}+0.162 X_{3}+0.521 X_{4} \\
+e
\end{gathered}
$$

Based on multiple linear regression equation above, the obtained product regression coefficient is equal to $(+) 0,071$. The coefficient indicates a positive relationship between the product variables and the decision to become a customer. The price regression coefficient is $(+) 0.252$. The coefficient indicates a positive relationship between the price variable and the decision to become a customer. The regression coefficient of place is $(+)$ 0.162. The coefficient indicates a positive relationship between place variables to the decision to become a customer. Meanwhile, the promotion regression coefficient is $(+)$ 0.521 . The coefficient indicates a positive relationship between promotion variable to the decision to become a customer.

Based on the beta coefficient of regression in table 3 it can be concluded that the promotion variable has the greatest influence on the decision to become a customer with the value of regression beta coefficient of $(+)$ 0.521, followed by variable price (+) 0.252 , place $(+) 0.162$, and product $(+) 0.071$.

From the results of T-Test, the hypotheses proposed following:
$\mathrm{H}_{1}$ : The product has a positive and significant effect on the decision to become a customer, the result of multiple regression analysis shows that the product has $\mathrm{t}$-count value $(1.178)<$ t-table $(1.660)$ $(\mathrm{df}=98, \operatorname{Pr}=0.05)$ which means $\mathrm{H}_{1}$ is rejected. It is also supported by the probability value of the product $(0.242)>0.005$;

$\mathrm{H}_{2}$ : Price has a positive and significant effect on the decision to become customer, the result of multiple regression analysis shows that the product has $\mathrm{t}$-count value (3.321) > t-table (1.660) $(\mathrm{df}=98, \operatorname{Pr}=0.05)$ which means $\mathrm{H}_{2}$ accepted. It is also supported by the probability value of the price $(0.001)<0.005$;

$\mathrm{H}_{3}$ : Places have a positive and significant effect on the decision to become customers, the results of multiple regression analysis indicate that the product has $\mathrm{t}$-count value (2.857) > t-table (1660) $(\mathrm{df}=98, \operatorname{Pr}=0.05)$ which means $\mathrm{H}_{3}$ accepted. It is also supported by the probability value of the place $(0.005)=0.005$;

$\mathrm{H}_{4}$ : The promotion has a positive and significant effect on the decision 
to become a customer, and promotion influence the result of multiple simultaneously on the regression analysis dependent variable of decision shows that the product to become a customer of sharia has $t$-count value (11.732) banking. While the rest $8.7 \%$ is $>$ t-table $(1.660)(\mathrm{df}=$ explained by other variables 98, $\operatorname{Pr}=0.05)$ which outside of this model.

means $\mathrm{H}_{4}$ accepted. It is also supported by the probability value of the price $(0.000)<0.005$.

Based on table 4, the

\section{Discussion}

\section{Product Variables}

Product Variable $\left(X_{1}\right)$ has an insignificant influence result shows that the adjusted $\mathrm{R}^{2}$ of 0.909 means $90.9 \%$ of the variation of the decision to become syariah banking customers can be explained by the variation of the four independent variables of product, price, place, and promotion. While the rest of $9.1 \%$ is explained by other understanding it can be seen

Table 4 on the decision to become a customer of sharia banking (Y). According to Feisal Abidin (2017), the term product can be defined as "a series of tangible and intangible attributes including functional, social, and psychological benefits or utilities". From this

\begin{tabular}{|c|c|c|c|c|}
\hline \multicolumn{5}{|c|}{ Model Summary } \\
\hline Model & $\mathrm{R}$ & $\begin{array}{l}\mathrm{R} \\
\text { Square }\end{array}$ & $\begin{array}{l}\text { Adjusted R } \\
\text { Square }\end{array}$ & $\begin{array}{l}\text { Std. Error } \\
\text { of the Esti- } \\
\text { mate }\end{array}$ \\
\hline 1 & $.956^{a}$ & .913 & .909 & .526 \\
\hline
\end{tabular}

variables outside the model.

that the product is not required

Based on table 4, it can in the form of a tangible be concluded that $\mathrm{R}$ square product, but its existence must value is 0.913 that means be able to meet the needs of 91.3\% of independent variable customers' in this research of product, price, place, that, hereinafter, referred 
to customers consisting of functional utilities, social, and psychological. In this study, product variables have no significant effect in influencing the decision to become syariah banking customers. In this study, the diverse items of products offered by syariah banking do not give a big influence on the decision to become a customer. This may be influenced by the public ignorance of sharia banking products. The results of this study differ from the one conducted by Detha Alfrian Fajri, Zainul Arifin, and Wilopo (2013: 1-10), which states that product variables influence purchasing decisions with $\mathrm{t}$ values greater than $\mathrm{t}$ table $(2.493>1.987)$ Significance is less than a $(0.015<0.05)$.

\section{Price Variables}

Price Variable $\left(X_{2}\right)$ has a significant influence on the decision to become a customer of sharia banking (Y). According to Zulhelmi and Albert (2016), price is the sum of money (plus some products, if possible) needed to obtain some combination of products and services. Based on that understanding, it can be seen that price is a sum of money that must be issued by customers to get the benefits of a product or service. In this study, it can be seen that customers' decisions are influenced by the cost of profit sharing and administrative costs in deciding to save in sharia banking. As it has already known that the difference between Conventional Bank and Islamic Bank is wide, one that distinguishes is the existence of the contract at the beginning of the transaction (akad) which, in Islam, the akad is the indicator of a worth reward activity (Okumus, 2005: 51-86). If there is a profit in the Islamic banking system because there is no fluctuating interest rate, then in conventional Bank the term is usually called flat interest. Thus, a substantially different price-related for sharia banking customers has an influence on the decision to save money at the bank. The result of this research is in line with the research conducted by Hesti Budiwati (2012: 1-16), which states that the price variable influences customers purchasing decision on the superior banana chips with the result of $t$ test on the price variable obtained $t$ value of -2.066 with significance of 0.029 . Using a $5 \%$ or 0.05 significance limit obtained $t$ table of \pm 1.980 . This means $t$ arithmetic <- $t$ table, which means Ho is rejected and $\mathrm{Ha}$ accepted. 


\section{Place Variables}

Place variable has a significant influence on the decision to become a customer of sharia banking (Y). According to Rianita Lasut (2017), the place is where the services are delivered and where the company and its consumers interact, as well as any components to facilitate the appearance or communication of such services. The choice of place/ location has a strategic function because it has participation in determining the achievement of corporate goals. Prospective customers believe that the location/place affects them to become customers in sharia banking, they feel comfortable when having transaction in the sharia banking office provided by the company, strategic location that is easy to reach, and a large parking area so that customers feel comfortable in doing financial transactions. So, it can be concluded that the variable of place, greatly affects the prospective customers in making decision to become customers of sharia banking. The results of this study are different from the research conducted by Christian AD Selang (2013: 71-80), which states that place variable does not affect consumer loyalty seen from $t$ test result that the $\mathrm{t}$ count $=-2.573>\mathrm{t}$ tabel $=1.984$ and significance $p$-value $=0.568$ $<0.05$, it can be concluded that $\mathrm{Ha}$ is rejected or Place has no effect on Consumer Loyalty.

\section{Promotion Variables}

Promotion variable $\left(X_{3}\right)$ has a significant influence on the decision to become a customer of sharia banking (Y). According to Beatric Kondoy (2016), the purpose of banking promotion is to inform all types of products offered by the bank and trying to attract new customers. Then the campaign also serves to remind customers of products, promotions also affect customers to buy the product, and ultimately promotion will also improve the image of the bank in the eyes of its customers. From this understanding, it can be seen that promotion is a business conducted by the bank in order to attract prospective customers and simultaneously improve the image of the bank in the eyes of customers.

The result of the study shows that promotion has an effect on making the decision to become syariah bank customers, thisresultstated that promoting is a very important activity to be implemented in product marketing. Through this promotion activity, 
the company tries to notify consumers of a product and encourages them to purchase the product. There are many ways that banks maight do to promote their products. Promotion is an activity aimed at influencing consumers so that they can recognize the products offered by the bank to them and then they become happy, then they buy the product. Promotion is also a part of a marketing tools that plays an important role in increasing the sales volume of goods and services offering to the consumers. The main purposes of promotion are to inform, influence, persuade, and remind the targeted customers about marketing and marketing mix. Promotion is done by giving discounts, interesting brochures, and through the SPG or employees (Zainal Abidin, 2017: 30-41). The result of this research is in accordance with the research conducted by Aldino Satria Graha (2017), which states that promotion variable influences consumer purchase decision with promotion sig value $(0,000)<0,05$, then $\mathrm{H}^{2}$, which stated promotion significantly influence to consumer satisfaction, is proven.

\section{CONCLUSION}

The empirical results indicate that the variable price, place, and promotion affect the customers' decision to become customers in sharia banking in Indonesia. While the product variable does not affect their decision. Then, when a simultaneous test done, it showed that all independent variables affect the decision to become a customer. This result implies that sharia banking should be able to improve the marketing mix process (price, place, and promotion, beside products) if they want to raise their number of customers.

Based on the results of the data analysis conducted by the researcher, it is known that the variables of price $\left(X_{2}\right)$, promotion $\left(X_{3}\right)$, and place $\left(X_{4}\right)$ are simultaneously or together have a significant influence on the decision making to become a customer $(\mathrm{Y})$, so the company should pay attention in terms of marketing mix thoroughly to increase the number of their spiritual and rational customers they have. (1) From the four dependent variables it is only product variables $\left(X_{1}\right)$ that has no effect on the decision making to become a customer $(\mathrm{Y})$. Therefore, the company is expected to be able to increase the significance of the product $\left(X_{1}\right)$ by marketing 
the products of sharia banking. knowing and recognizing (2) Through this research, the expected marketing mix marketing mix is needed to be expeceted by customers. (3) studied further in accordance For future researchers, this with customer's expectation research is expected to be used because the customer's as a reference and comparison requirement and taste will inconducting similar researchs always change following the in the future, especially the existing developments. This study about marketing mix can be done by conducting and its effect on the customer further researches with specific decision making to become a time adjusted to the needs customer of a certain bank. of the company to continue 


\section{REFERENCES}

Abidin. Feisal., Arifin. Zainul., Yulianto. Edy. (2017). Pengaruh Service Marketing Mix (Bauran Pemasaran Jasa) Terhadap Citra Merek Dan Dampaknya Pada Keputusan Pembelian (Survei kepada Pengguna Armada Bus Pariwisata PO. Anto Wijaya Tour Ponorogo). Jurnal Administrasi Bisnis (JAB), Vol. 44, No. 1: 47-53.

Abidin. Zainal., Harahab. Nuddin., Boimin. (2017). Analisis Strategi Bauran Pemasaran Terhadap Keputusan Pembelian Bandeng Presto "Bu Jeni" Di Kota Malang, Jawa Timur. ECSOFiM: Journal of Economic and Social of Fisheries and Marine. Vol. 05, No. 01: 30-41.

Arikunto. Suharsimi. (2003). Manajemen Penelitian. Jakarta: Renika Cipta.

Budiwati. Hesti. (2012). Implementasi Marketing Mix dan Pengaruhnya terhadap Keputusan Pembelian Konsumen pada Produk Unggulan Keripik Pisang Agung di Kabupaten Lumajang. Jurnal WIGA, Vol. 2, No. 2: 1-16.

Christian AD. Selang. (2013). Bauran Pemasaran (Marketing Mix) Pengaruhnya terhadap Loyalitas Konsumen Pada Fresh Mart Bahu Mall Manado. Jurnal EMBA, Vol.1, No.3, 71-80.

Erol, C., Kaynak, E., El-Bdour, R. (1990). Conventional and Islamic Bank: Patronage Behaviour of Jordanian Customers. International Journal of Bank Marketing, Vol. 8 No. 5: 25-35.

Fajri. Detha Alfrian., Arifin. Zainul., Wilopo. (2013). Pengaruh Bauran Pemasaran Jasa Terhadap Keputusan Menabung (Survei Pada Nasabah Bank Muamalat Cabang Malang). Jurnal Administrasi Bisnis (JAB), Vol. 6, No. 2: 1-10.

Graha. Aldino Satria. (2017). Pengaruh Bauran Promosi Terhadap Kinerja Ekspor (Studi kasus pada PT. KMI Wire and Cable Tbk Eksportir Kabel). Jurnal Administrasi Bisnis (JAB), Vol. 46, No. 1: 156-162.

Husaeni. Uus Ahmad. (2017). Determinan Pembiayaan Pada Bank Pembiayaan Rakyat Syariah Di Indonesia. Esensi: Jurnal Bisnis dan Manajemen, Vol. 7, No. 1: 49-62.

Husaeni. Uus Ahmad., Saepudin. Dadan. (2017). Spiritual Marketing: a Strategy to Increased Number of Islamic Banking Customer in Cianjur, West Java, Indonesia" International Journal of Advanced Research, Vol. 5, No. 
2: 1117-1121.

Kondoy. Beatric M . J. (2016). Bauran Pemasaran Dan Pengaruhnya Terhadap Keputusan Menjadi Nasabah Di BPR Prisma Dana Manado. Jurnal EMBA. Vol. 4, No. 4: 1025-1036.

Kotler. Philip., Amstrong, G. (2014). Prinsip-prinsip Pemasaran. Jilid 2. Edisi Bahasa Indonesia. Jakarta: Erlangga.

Lasut. Rianita., Tumbel. Altje L. (2017). Pengaruh Bauran Promosi Terhadap Keputusan Pembelian Pada PT. Astra International TBK-Daihatsu Cabang Malalayang Manado (Studi Kasus Pada Pembeli Produk Ayla). Jurnal EMBA. Vol. 5, No. 2: 1452-1462.

Nugroho. Anton Yohanes. (2011). It's Easy Olah Data Dengan SPSS. Yogyakarta: Skripta Media Creative.

Okumus. H. (2005). Interest-Free Banking in Turkey: A Study of Customer Satisfactin and Bank Selection Criteria. Journal of Economic Cooperation, Vol. 26, No. 4: 51-86.

Peter, J. P., J.C. Olson. (2013). Perilaku Konsumen dan Strategi Pemasaran. Edisi 9. Jilid 1. Alih Bahasa: Diah Tantri

Dwiandani. Jakarta: Salemba Empat.

Santoso. Singgih. (2012). Panduan Lengkap SPSS Versi 20. Jakarta: Penerbit PT Elex Media Komputindo.

Sobana. Dadang Husen., Husaeni. Uus Ahmad. (2016). The Variables that Affect Compliance of Muslim Merchants for Zakat Maal in the District of Cianjur. International Journal of Zakat, Vol. 1, No.1: 78-87.

Sugiyono. (2007). Metode Penelitian Kuantitatif, Kualitatif dan R \& D. Bandung: Alfabeta.

Sumarni. Murti., (2002). Manajemen Pemasaran Bank. Yogyakarta: Penerbit Liberty.

Tjiptono. Fandy. (2011). Pemasaran Jasa. Yogyakarta: Bayumedia. Wulan. Elis Ratna., Husaeni. Uus Ahmad. (2015). Analysis of the Variables that Affect Bookstore Customer Satisfaction. International Journal of Nusantara Islam, Vol. 3, No. 2: 27-36.

Zulhelmi., Albert. (2016). Analisis Pengaruh Produk, Harga, Promosi, Tempat Terhadap Keputusan Pembelian Produk Sparepart Sepeda Motor Merek Strong Di Pekanbaru. Procuratio. Vol. 04, No. 03: 385-404. 